\title{
МАРКЕРИ ЛІЗОСОМАЛЬНОГО УШКОДЖЕННЯ ЗА УМОВИ КОМБІНОВАНОЇ ДІЇ К-КАРАГІНАНУ ТА НАТРІЮ ГЛУТАМАТУ В ЕКСПЕРИМЕНТІ
}

Вступ. Наукові дослідження підкреслюють невирішені питання вивчення карагінанів, зокрема зв'язок між фрізико-хімічними властивостями карагінану, його впливом на травний протеоліз, мікробіом товстої кишки і запалення, а також його ефректи в різних групах ризику, що вказує на необхідність проведення подальших досліджень для з'ясування можливого його токсичного впливу за умов постійного підвищення рівня карагінану в раціоні людини та широкого поєднання різних харчових добавок.

Мета дослідження - оцінити показники лізосомального ушкодження (активність кислої фросфратази і катепсину В) в тканинах організму щурів за умови комбінованої дії к-карагінану та натрію глутамату.

Методи дослідження. Дослідження проведено на 48 білих нелінійних щурах-самцях, яких поділили на 4 групи: контрольну (інтактні тварини) і 3 дослідних (1-ша - щури, яким внутрішньошлунково вводили к-карагінан у дозі 40 мг/кг протягом 1 місяця; 2-га - тварини, яким внутрішньошлунково вводили натрію глутамат у дозі 50 мг/кг упродовж 1 місяця; 3-тя - щури, яким внутрішньошлунково вводили к-карагінан і натрію глутамат у вищевказаних дозах). Активність кислої фросфратази і катепсину в у крові, легенях та печінці щурів визначали за стандартними методиками.

Результати й обговорення. Встановлено вірогідно вищу активність кислої фросфратази у сироватці крові, а також у печінці й легенях щурів 1-ї і 2-ї дослідних груп щодо контролю. Варто відмітити найбільші їі значення у тварин 3-ї дослідної групи, які були достовірно вищими у сироватці крові (на 90,20 \%), а також у печінці (на 69,60 \%) і легенях (на 82,20 \%) щурів стосовно контролю. Встановлено вірогідно вищу активність катепсину В у сироватці крові, а також у печінці й легенях щурів 1-ї і 2-ї дослідних груп щодо контролю. Варто відзначити найбільші ї̈ значення у тварин 3-ї дослідної групи, які були достовірно вищими у сироватці крові (на 97,70 \%), а також у печінці (на 52,10\%) і легенях (на 83,10 \%) щурів стосовно контролю.

Висновок. За умови комбінованої дії розчинів к-карагінану та натрію глутамату вірогідно збільшується активність кислої фросфратази і катепсину В у сироватці крові (на 90,2 та 97,7 \%), печінці (на 69,6 та 52,1 \%) і легенях (на 82,2 та 83,1 \%) щурів відносно контролю, що також статистично значимо вище проти значень цих показників при окремому застосуванні к-карагінану і натрію глутамату.

КЛЮЧОВІ СЛОВА: к-карагінан; натрію глутамат; кисла фоссратаза; катепсин В; кров; печінка; легені.

ВСТУП. Однією з найпоширеніших харчових добавок у продуктах харчування на даний час $\epsilon$ натрію глутамат (Е621), який ще називають "китайською сіллю". Окрім ефекту посилення смаку, на думку дослідників, натрію глутамат асоціюється з токсичною дією, зокрема, він пов'язаний з ожирінням, порушенням обміну речовин, синдромом китайських ресторанів, нейротоксичною дією та шкідливими есектами на репродуктивні органи [1]. 3 іншого боку, в Європейському Союзі E621 дозволений у деяких продуктах харчування та обмежений кількісно [2]. Під час дослідження, яке провела в 1995 р. Федерація американських товариств експериментальної (с П. І. Бучко, М. І. Марущак, 2021. біології (FASEB) для Управління з контролю за продуктами та ліками (FDA), було встановлено, що немає даних, які підтверджують роль натрію глутамату у виникненні або ускладненні хронічних захворювань [3-5]. Незважаючи на те, що натрію глутамат, імовірно, має величезні переваги для харчової промисловості, широке використання цієї харчової добавки може негативно впливати на здоров'я населення.

Карагінани використовують насамперед як загусники у харчовій промисловості завдяки їх гелеутворювальним, емульгувальним та стабілізувальним властивостям [6-8]. На даний час їх застосовують під час медичних, фрармацевтичних та біотехнологічних досліджень. Карагінани 
“загальновизнані безпечними" FDA 31973 р. Карагінан E407 та напіврафрінований карагінан E407a Європейський орган з безпеки харчових продуктів затвердив як харчові добавки. Результати досліджень токсикологічних аспектів карагінанів показали, що вони мають мінімальні несприятливі фрізіологічні ефекти або вони взагалі відсутні [9]. Проте S. David та співавт. [10] підкреслюють невирішені питання вивчення карагінанів, зокрема зв'язок між фрізико-хімічними властивостями карагінану, його впливом на травний протеоліз, мікробіом товстої кишки і запалення, а також його ефекти в різних групах ризику, що вказує на необхідність проведення подальших досліджень для з'ясування можливого його токсичного впливу за умов постійного підвищення рівня карагінану в раціоні людини, а також широкого поєднання різних харчових добавок.

Мета дослідження - оцінити показники лізосомального ушкодження (активність кислої фоссратази і катепсину В) в тканинах організму щурів за умови комбінованої дії к-карагінану та натрію глутамату.

МЕТОДИ ДОСЛІДЖЕННЯ. Дослідження проведено на 48 білих нелінійних щурах-самцях, яких утримували на стандартному раціоні віварію Тернопільського національного медичного університету імені І. Я. Горбачевського МO3 України. Під час роботи дотримувалися принципів Європейської конвенції про захист хребетних тварин, що використовуються для дослідних та інших наукових цілей (Страсбург, 1986). Піддослідних тварин поділили на 4 групи по 12 щурів у кожній: контрольну (інтактні тварини) і 3 дослідних (1-ша - щури, яким внутрішньошлунково вводили к-карагінан у дозі 40 мг/кг, розчинений у 0,5 мл дистильованої води кімнатної температури, протягом 1 місяця [11, 12]; 2-га - тварини, яким внутрішньошлунково вводили натрію глутамат у дозі 50 мг/кг, розчинений у 0,5 мл дистильованої води кімнатної температури, впродовж 1 місяця [13]; 3-тя-щури, яким внутрішньошлунково вводили к-карагінан і натрію глутамат у вищевказаних дозах).

Для приготування 10 \% гомогенату відібрані відразу ж після евтаназії зразки легень і печінки охолоджували у фрізіологічному розчині до 1-3 ${ }^{\circ} \mathrm{C}$, підсушували фрільтрувальним папером, потім подрібнювали ножицями та гомогенізували в 0,05 М трис-НCl буфрері $(\mathrm{pH} 7,4)$ за допомогою магнітного гомогенізатора "SilentCrusher S" ("Неidolp", Німеччина) у співвідношенні 1:9 (маса тканини/об'єм бусрера). Отриманий гомогенат центрифугували протягом 30 хв при 3000 об./хв на центрифузі з охолодженням "Hermle Z 32 HK".
Активність катепсинів визначали в лейкоцитах крові, легенях і печінці щурів за методичними принципами, які викладено в праці A. Barret i H. Kirschke [14], із субстратами N2-бензоілDLapгінін-4-нітроаніліду (катепсин B). Активність катепсину В виражали в наномолях паранітроаніліну, який відщепився від субстрату за годину інкубації, на 1 мг протеїну. Вміст протеїну визначали за однією з модиорікацій методу Лоурі [15].

Активність кислої фоссфатази (КФ) визначали у сироватці крові та гомогенаті легень і печінки при рН 4,8. Субстратом для дії ензимів слугував п-нітрофенілфосфрат натрію, який під впливом фоссратаз гідролізується до п-нітрофенолу, що має жовте забарвлення [16]. Інтенсивність забарвлення пропорційна активності ензимів. Оптичну густину вимірювали на спектрофротометрі СФ-46. Активність ензимів виражали у мккат/л або мккат/кг.

Статистичну обробку результатів проводили 3 використанням комп'ютерних програм STATISTICA 7.0 й Excel 2007. Вибір методу статистичного дослідження базувався на правильності розподілу досліджуваних ознак. Зважаючи на неправильний розподіл кількісних характеристик, їх описову статистику здійснювали у вигляді reported as medians and interquartile range (IQ, percentile 25 and percentile 75 ). Подальше попарне порівнювання груп проводили 3 використанням U-критерію Манна - Уїтні при оцінці рівня статистичної значущості $p<0,05$.

РЕЗУЛЬТАТИ Й ОБГОВОРЕННЯ. ВраховУючи те, що кисла фросфатаза є маркерним ензимом стабільності лізосом, ми проаналізували її активність у тканинах тварин при комбінованій дії харчових добавок. У щурів 1-ї дослідної групи встановлено вірогідно більшу активність КФ у сироватці крові (на 26,50 \%), а також у печінці (на 35,70 \%) і легенях (на 22,50 \%) тварин стосовно контролю. У щурів 2-ї дослідної групи вона також була достовірно вищою у сироватці крові (на 36,80 \%), а також у печінці (на 30,40 \%) і легенях (на 57,40 \%) тварин щодо контролю. Варто відмітити найбільші значення активності КФ у щурів 3-ї дослідної групи, які були вірогідно вищими у сироватці крові (на 90,20 \%), а також у печінці (на 69,60 \%) і легенях (на 82,20 \%) тварин відносно контролю (табл. 1). При цьому комбіноване застосування харчових добавок в експерименті характеризувалось достовірно більшими значеннями активності КФ стосовно даних у печінці тварин 1-ї (на 33,90 \%) і 2-ї (на 39,20 \%) дослідних груп, а також, відповідно, у легенях (на 59,70 та 24,80 \%) і сироватці крові (на 63,70 та 53,40 \%) (рис.). 
Таблиця 1 - Активність кислої фоссратази (мккат/л(кг)) у тканинах щурів при комбінованій дії харчових добавок

\begin{tabular}{||l|c|c|c||}
\hline \multicolumn{1}{|c|}{ Група тварин } & Сироватка крові & Легені & Печінка \\
\hline Контрольна & 1,17 & 0,65 & 0,28 \\
& $(1,08 ; 1,22)$ & $(0,61 ; 0,70)$ & $(0,24 ; 0,31)$ \\
\hline 1-ша дослідна & 1,48 & 0,79 & 0,38 \\
(к-карагінан) & $(1,46 ; 1,53)$ & $(0,75 ; 0,82)$ & $(0,36 ; 0,41)$ \\
& $p_{1}<0,05$ & $p_{1}<0,05$ & $p_{1}<0,05$ \\
& $p_{2}<0,05$ & $p_{2}<0,05$ & $p_{2}>0,05$ \\
\hline 2-га дослідна & 1,60 & 1,02 & 0,37 \\
(натрію глутамат) & $(1,57 ; 1,65)$ & $(0,89 ; 1,10)$ & $(0,34 ; 0,40)$ \\
& $p_{1}<0,05$ & $p_{1}<0,05$ & $p_{1}<0,05$ \\
& $p_{3}<0,05$ & $p_{3}<0,05$ & $p_{3}<0,05$ \\
\hline 3-тя дослідна & 2,23 & 1,18 & 0,48 \\
(к-карагінан+натрію глутамат) & $(2,18 ; 2,30)$ & $(1,12 ; 1,26)$ & $(0,45 ; 0,51)$ \\
& $p_{1}<0,05$ & $p_{1}<0,05$ & $p_{1}<0,05$ \\
& $p_{4}<0,05$ & $p_{4}<0,05$ & $p_{4}<0,05$ \\
\hline \hline
\end{tabular}

Примітка. Тут і в таблиці 2: $\mathrm{p}_{1}$ - зміни достовірні відносно показників інтактних тварин; $\mathrm{p}_{2}$ - достовірність змін між 1-ю і 2-ю дослідними групами; $p_{3}$ - достовірність змін між 2-ю і 3-ю дослідними групами; $\mathrm{p}_{4}$ - достовірність змін між 1-ю і 3-ю дослідними групами.

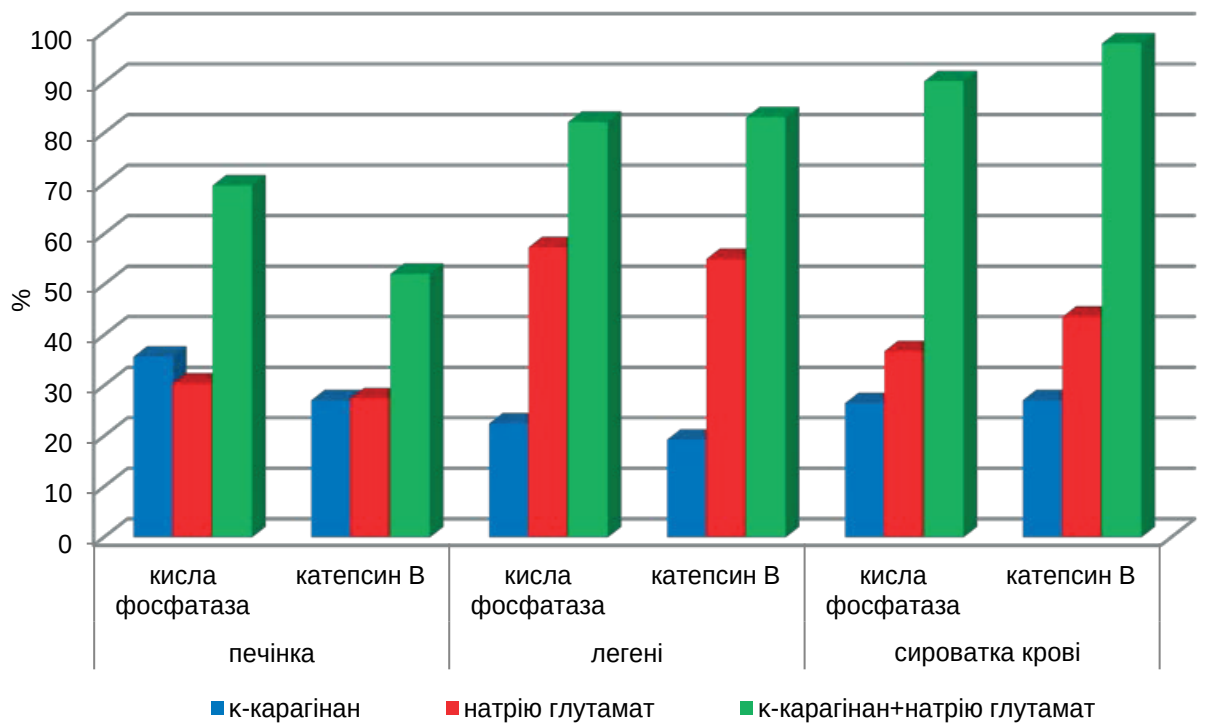

Рис. Зіставлення активності кислої фроссратази і катепсину В у тканинах щурів за умови комбінованої дії к-карагінану та натрію глутамату.

Пряме ушкодження лізосом можна оцінити за активністю КФ, порушення проникності їх мембрани - за активністю катепсинів [17]. Катепсини, що виходять у цитозоль, руйнують позаклітинний матрикс, зумовлюючи апоптоз. У щурів 1-ї дослідної групи встановлено вірогідно більшу активність катепсину В у сироватці крові (на 27,10 \%), а також у печінці (на 27,10\%) і легенях (на 19,30 \%) тварин стосовно контролю. У щурів 2-ї дослідної групи вона також була достовірно вищою у сироватці крові (на 43,60 \%), а також у печінці (на 27,50 \%) і легенях (на $55,10 \%$ ) тварин щодо контролю. Варто відмітити найбільші значення активності катепсину В у щурів 3-ї дослідної групи, які були вірогідно вищими у сироватці крові (на 97,70 \%), а також у печінці (на 52,10 \%) і легенях (на 83,10 \%) тварин відносно контролю (табл. 2). При цьому комбіноване застосування харчових добавок в експерименті характеризувалось достовірно більшими значеннями активності катепсину В стосовно даних у печінці тварин 1-ї (на 25,00 \%) і 2-ї (на 24,60 \%) дослідних груп, а також, відповідно, у легенях (на 63,80 \% та 28,00 \%) і сироватці крові (на 70,60 та 54,10 \%) (рис.).

При зіставленні маркерів лізосомального ушкодження встановлено найвищі значення активності КФ і катепсину В за умови комбінованої дії к-карагінану та натрію глутамату. Також виявлено найменші значення досліджуваних показників у легенях щурів при застосуванні к-карагінану, тоді як використання натрію глутамату в експерименті супроводжувалося найбільшими їх значеннями в легенях (рис.) 
Таблиця 2 - Активність катепсину В (нмоль/годхмг протеїну) в тканинах щурів при комбінованій дії харчових добавок

\begin{tabular}{||l|c|c|c||}
\hline \multicolumn{1}{|c|}{ Група тварин } & Лейкоцити крові & Легені & Печінка \\
\hline Контрольна & 1,09 & 1,04 & 1,20 \\
& $(0,93 ; 1,19)$ & $(0,87 ; 1,25)$ & $(0,91 ; 1,40)$ \\
\hline 1-ша дослідна & 1,39 & 1,24 & 1,53 \\
(к-карагінан) & $(1,36 ; 1,42)$ & $(1,18 ; 1,29)$ & $(1,48 ; 1,57)$ \\
& $\mathrm{p}_{1}<0,05$ & $\mathrm{p}_{1}<0,05$ & $\mathrm{p}_{2}<0,05$ \\
& $\mathrm{p}_{2}<0,05$ & $\mathrm{p}_{2}<0,05$ & 1,53 \\
\hline 2-га дослідна & 1,57 & 1,61 & $(1,46 ; 1,57)$ \\
(натрію глутамат) & $(1,51 ; 1,60)$ & $(1,56 ; 1,66)$ & $\mathrm{p}_{1}<0,05$ \\
& $\mathrm{p}_{1}<0,05$ & $\mathrm{p}_{1}<0,05$ & $\mathrm{p}_{3}<0,05$ \\
\hline 3-тя дослідна & $\mathrm{p}_{3}<0,05$ & $\mathrm{p}_{3}<0,05$ & 1,83 \\
(к-карагінан+натрію глутамат) & 2,16 & 1,90 & $(1,78 ; 1,89)$ \\
& $(2,09 ; 2,25)$ & $(1,85 ; 1,97)$ & $\mathrm{p}_{1}<0,05$ \\
& $\mathrm{p}_{1}<0,05$ & $\mathrm{p}_{1}<0,05$ & $\mathrm{p}_{4}<0,05$ \\
\hline
\end{tabular}

Результати, які ми отримали, свідчать про зростання активності показників лізосомального ушкодження (кислої фросфатази і катепсину В) у сироватці крові, печінці й легенях щурів. Оскільки досліджувані параметри є непрямими маркерами апоптозу, вважаємо, що в поєднанні з активацією білкової і ліпідної пероксидації комбінована дія к-карагінану та натрію глутамату супроводжується підвищеною апоптичною загибеллю.
ВИСНОВОК. За умови комбінованої дії розчинів К-карагінану та натрію глутамату вірогідно збільшується активність кислої фосфратази і катепсину В у сироватці крові (на 90,2 та 97,7 \%), печінці (на 69,6 та 52,1 \%) і легенях (на 82,2 та 83,1 \%) щурів відносно контролю, що також статистично значимо вище проти значень цих показників при окремому застосуванні к-карагінану і натрію глутамату.

\section{СПИСОК ЛІТЕРАТУРИ}

1. Niaz K. Extensive use of monosodium glutamate: A threat to public health? / K. Niaz, E. Zaplatic, J. Spoor // EXCLI J. - 2018. - 17. - P. 273-278. DOI:10.17179/ excli2018-1092.

2. Aramesh M. Alkaline protease producing Bacillus isolation and identification from Iran / M. Aramesh, $\mathrm{H}$. Ajoudanifar // Banat's Journal of Biotechnology. 2017. - 8 (16). - P. 140-147.

3. In vitro bioassay investigations of suspected obesogen monosodium glutamate at the level of nuclear receptor binding and steroidogenesis / M. Shannon, J. Wilson, Y. Xie [et al.] // Toxicology Letters. - 2019. 301. - P. 11-16.

4. Investigation of the induced antibiosis resistance by zinc element in different cultivars of sugar beet to long snout weevil, Lixus incanescens (Col: Curculionidae) / F. Hariri Moghadam, J. Khalghani, S. Moharramipour [et al.] // Banat's Journal of Biotechnology. - 2018. 9 (17). - P. 5-12.

5. Characterization of the quality of the steamed yoghurts enriched by dates flesh and date powder variety H'loua / A. Hariri, N. Ouis, D. Bouhadi [et al.] // Banat's Journal of Biotechnology. - 2018. - 9 (17). - P. 31-39.

6. Carrageenans: Biological properties, chemicalmodifications and structural analysis - A review /
V. L. Campo, D. F. Kawano, D. B. da Silva, I. Carvalho // Carbohydr. Polym. - 2009. - 77. - P. 167-180.

7. Review for carrageenan-based pharmaceutical biomaterials: Favourable physical features versus adverse biological e_ects. / J. Liu, X. Zhan, J. Wan // Carbohydr. Polym. - 2015. - 121. - P. 27-36.

8. Marushchak M. I. The features of oxidative processes in the wall of small intestine in rats with chronic enterocolitis combined with experimental diabetes / M. I. Marushchak, I. Y. Krynytska, N. V. Lisnyanska // Азербайджан. мед. журн. - 2019 (1). C. 102-106.

9. Cohen S. M. A critical review of the toxicological effects of carrageenan and processed eucheuma seaweed on the gastrointestinal tract / S. M. Cohen, N. Ito // Crit. Rev. Toxicol. - 2002. - 32. - P. 413-444.

10. Revisiting the carrageenan controversy: do we really understand the digestive fate and safety of carrageenan in our foods? / S. David, L. Levi, Y. Fahoum [et al.] // Food Funct. - 2018. - 9 (3). - P. 1344-1352.

11. Пат. 97322 Україна, MПK G09B 23/28. Спосіб моделювання хронічного гастроентероколіту / Іваненко Т. О., Коробчанський В. О., Губіна-Вакулик Г. І., Горбач Т. В., Колоусова Н. Г. - № а201014510 ; заявл. 06.12.10 ; опубл. 25.01.12, Бюл. № 2. 
12. Moyana T. N. Carrageenan-induced intestinal injury in the rat - a model for inflammatory bowel disease I T. N. Moyana, J. M. Lalonde // Ann. Clin. Lab. Sci. 1990. - 20. - 6. - P. 420-426.

13. Влияние глипролинов на структурно-срункциональное состояние слизистой оболочки желудка и массу тела крыс в условиях длительного введения глутамата натрия / Т. М. Фалалеева, Г.Е.Самонина, Т. В. Береговая [и др.] // Фізика живого. - 2010. - 18, № 1. - C. 154-159.

14. BarretA. Methods in enzymology. Ed.: L. Loran. / A. Barret, H. Kirschke, B. H. Cathepsins // New-York, London: Acad. press. - 1981. - 80, part C. - P. 535-561.
15. Hartree T. Determination of protein: A modification of Lowry method that gives a linear photometric response / T. Hartree // Anal. Biochem. - 1972. - 48, No. 2. - P. 422-427.

16. Левицкий А. П. Экспериментальные методы исследования стимуляторов остеогенеза : метод. рек. / [А. П. Левицкий, О. А. Макаренко, О. В. Деньга и др.]. - К. : ГФЦ, 2005. - 30 c.

17. Terman A. Lysosomal labilization / A. Terman // IUBMB Life. - 2006. - 58. - P. 531-539.

\section{REFERENCES}

1. Niaz, K., Zaplatic, E., \& Spoor, J. (2018). Extensive use of monosodium glutamate: A threat to public health? EXCLI J., (17) 273-278. DOI:10.17179/excli2018-1092.

2. Aramesh, M., \& Ajoudanifar, H. (2017). Alkaline protease producing Bacillus isolation and identification from Iran. Banat's Journal of Biotechnology, 8 (16), 140147.

3. Shannon, M., Wilson, J., \& Xie, Y. (2019). In vitro bioassay investigations of suspected obesogen monosodium glutamate at the level of nuclear receptor binding and steroidogenesis. Toxicology Letters, 301, 11-16.

4. Hariri Moghadam, F., Khalghani, J., \& Moharramipour, S. (2018). Investigation of the induced antibiosis resistance by zinc element in different cultivars of sugar beet to long snout weevil, Lixus incanescens (Col: Curculionidae). Banat's Journal of Biotechnology, 9 (17), 5-12.

5. Hariri, A., Ouis, N., \& Bouhadi, D. (2018). Characterization of the quality of the steamed yoghurts enriched by dates flesh and date powder variety H'loua, Banat's Journal of Biotechnology, 9 (17), 31-39.

6. Campo, V.L, Kawano, D.F, Silva, D.B., \& Carvalho, I. (2009). Carrageenans: Biological properties, chemicalmodifications and structural analysis - Areview. Carbohydr. Polym., 77, 167-180.

7. Liu, J., Zhan, X., Wan, J., Wang, Y., \& Wang, C. (2015). Review for carrageenan-based pharmaceutical biomaterials: Favourable physical features versus adverse biological effects. Carbohydr. Polym., 121, 27-36.

8. Marushchak, M.I., Krynytska, I.Y., \& Lisnyanska, N.V. (2019). The features of oxidative processes in the wall of small intestine in rats with chronic enterocolitis combined with experimental diabetes. Azerbaydzhanskiy meditsinskiy zhurnal -Azerbaidzan Medical Journal, (1), 102-106.

9. Cohen, S.M., \& Ito, N.A. (2002). Critical review of the toxicological effects of carrageenan and processed eucheuma seaweed on the gastrointestinal. tract. Crit. Rev. Toxicol., 32, 413-444.

10. David, S., Levi, C.S., Fahoum, L., Ungar, Y.E., Meyron-Holtz, G., Shpigelman, A., et al. (2018). Revisiting the carrageenan controversy: do we really understand the digestive fate and safety of carrageenan in our foods?. Food Funct., 9 (3), 1344-1352.

11. Ivanenko, T., Korobchanskiy, V., Hubina-Vakulik, H., Horbach, T., \& Kolusova, N. Sposib modeliuvannia khronichnono hastroenterokolitu [A method of modeling chronic gastroenterocolitis]. Patent 97322 Ukraine, MPK G09B 23/28/ № a201014510, stat. 06.12.2010, publich. 25.01.2012, byuil № 2. [in Ukrainian].

12. Moyana, T.N. (1990). Carrageenan-induced intestinal injury in the rat - a model for inflammatory bowel disease. Ann. Clin. Lab. Sci., 20 (6), 420-426.

13. Fleeva, T., Samonina, H., \& Berehovaya, T. (2010). Vliyanie hliprolinov na strukturno-funktsionalnoe sostoyanie slizistoy obolochky zheludka i masy tela krys v usloviyakh dlitelnogo vvedenia glutamata natriya [Influence of glyprolines on the structural and functional state of the gastric mucosa and body weight of rats under conditions of long-term administration of monosodium glutamate]. Fizika zhivoho - Physics of the Living, 18 (1), 154-159 [in Russian].

14. Barret, A, Kirschke, H. Cathepsins B, H, Loran, L. Methods in enzymology. New-York, London: Acad. press. 1981, 80 (C), 535-561.

15. Hartree, T. (1972). Determination of protein: A modification of Lowry method that gives a linear photometric response. Anal. Biochem., 48 (2), 422-427.

16. Levitskiy, A. (2005). Eksperimentalnye metody isledovaniya stimulatorov osteogeneza [Experimental methods for the study of osteogenesis stimulants]. HFZ, 30 [in Russian].

17. Terman, A. (2006). Lysosomal labilization. IUBMB Life, 58, 531-539. 
П. И. Бучко, М. И. Марущак

\title{
МАРКЕРЫ ЛИЗОСОМАЛЬНОГО ПОВРЕЖДЕНИЯ ПРИ КОМБИНИРОВАННОМ ДЕЙСТВИИ К-КАРРАГИНАНА И НАТРИЯ ГЛУТАМАТА В ЭКСПЕРИМЕНТЕ
}

\begin{abstract}
Резюме
Вступление. Научные исследования подчеркивают нерешенные вопросы изучения каррагинанов, в частности связь между физико-химическими свойствами каррагинана, его влиянием на пищеварительный протеолиз, микробиом толстой кишки и воспаление, а также его эффректы в различных группах риска, что указывает на необходимость проведения дальнейших исследований для выяснения возможного его токсического влияния в условиях постоянного повышения уровня каррагинана в рационе человека и широкого сочетания различных пищевых добавок.

Цель исследования - оценить показатели лизосомального повреждения (активность кислой фросфратазы и катепсина В) в ткканях организма крыс при комбинированном действии к-каррагинана и натрия глутамата.

Методы исследования. Исследование проведено на 48 белых нелинейных крысах-самцах, которых разделили на 4 группы: контрольную (интактные животные) и 3 исследовательских (1-я-крысы, которым внутрижелудочно вводили к-каррагинан в дозе 40 мг/кг на протяжении 1 месяца; 2-я-животные, которым внутрижелудочно вводили натрия глутамат в дозе 50 мг/кг в течение 1 месяца; 3-я - крысы, которым внутрижелудочно вводили к-каррагинан и натрия глутамат в вышеуказанных дозах). Активность кислой фосфратазы и катепсина В в крови, легких и печени крыс определяли по стандартным методикам.

Результаты и обсуждение. Установлено достоверно более высокую активность кислой фросфратазы в сыворотке крови, а также в печени и легких крыс 1-й и 2-й исследовательских групп относительно контроля. Стоит отметить крупнейшие ее значения у животных 3-й исследовательской группы, которые были достоверно выше в сыворотке крови (на 90,20\%), а также в печени (на 69,60 \%) и легких (на 82,20 \%) крыс по отношению к контролю. Установлено достоверно более высокую активность катепсина В в сыворотке крови, а также в печени и легких крыс 1-й и 2-й исследовательских групп относительно контроля. Стоит отметить крупнейшие ее значения у животных 3-й исследовательской группы, которые были достоверно выше в сыворотке крови (на 97,70\%), а также в печени (на 52,10 \%) и легких (на 83,10 \%) крыс по отношению к контролю.

Вывод. В условиях комбинированного действия растворов к-каррагинана и натрия глутамата достоверно увеличивается активность кислой фросфратазы и катепсина В в сыворотке крови (на 90,2 и 97,7 \%), печени (на 69,6 и 52,1 \%) и легких (на 82,2 и 83,1 \%) крыс относительно контроля, что также статистически значимо выше против значений этих показателей при раздельном применении к-каррагинана и натрия глутамата.
\end{abstract}

КЛЮЧЕВЫЕ СЛОВА: к-каррагинан; натрия глутамат; кислая фросфатаза; катепсин В; кровь; печень; легкие.

P. I. Buchko, M. I. Marushchak

I. HORBACHEVSKY TERNOPIL NATIONAL MEDICAL UNIVERSITY

\section{MARKERS OF LYSOSOMAL DAMAGE IN THE COMBINED ACTION OF K-CARRAGEENAN AND MONOSODIUM GLUTAMATE IN THE EXPERIMENT}

\section{Summary}

Introduction. Research highlights unresolved issues in the study of carrageenans, including the relationship between the physicochemical properties of carrageenan, its effect on digestive proteolysis, colon microbiome, and inflammation; as well as its effects in different risk groups, which indicates the need for further research to determine its possible toxic effects in the case of increasing levels of carrageenan in the human diet, as well as a wide combination of different supplements.

The aim of the study - to evaluate the indicators of lysosomal damage (acid phosphatase and cathepsin B activity) in the tissues of rats under the combined action of $\mathrm{K}$-carrageenan and monosodium glutamate. 
Research Methods. The study was carried out on 48 white nonlinear male rats, which were divided into 4 groups: control (intact animals), 1 - animals that were intragastrically injected with $\mathrm{k}$-carrageenan at a dose of $40 \mathrm{mg} / \mathrm{kg}$ for 1 month, 2 - animals, which were intragastrically injected sodium glutamate at a dose of $50 \mathrm{mg} / \mathrm{kg}$ for 1 month, 3 - animals that were intragastrically injected with carrageenan and sodium glutamate in the above doses. The activity of acid phosphatase and cathexin B in the blood, lungs and liver of rats was determined by standard methods.

Results and Discussion. Significantly higher acid phosphatase activity was found in 1 and 2 experimental groups in the serum, as well as in the liver and lungs of rats, in relation to control. It should be noted the highest values of acid phosphatase activity in animals of the experimental group 3, which were probably higher in the serum (by $90.20 \%$ ), as well as in the liver (by $69.60 \%$ ) and lungs (by $82.20 \%$ ) of rats, relative to control. Significantly higher activity of cathepsin B in experimental groups 1 and 2 in the serum, as well as in the liver and lungs of rats, relative to control. It should be noted the highest values of cathepsin $B$ activity in animals of the experimental group 3 , which were probably higher in the serum (97.70\%), as well as in the liver (52.10\%) and lungs (83.10\%) of rats, regarding control.

Conclusions. In the combined action of solutions of $k$-carrageenan and monosodium glutamate, the activity of acid phosphatase and cathepsin B in serum (by $90.2 \%$ and $97.7 \%$ ), liver (by $69.6 \%$ and $52.1 \%$ ) and lungs is likely (by $82.2 \%$ and $83.1 \%$ ) of rats increase relative to control, which is also statistically significantly higher against the values of these indicators with separate use of $k$-carrageenan, as well as monosodium glutamate.

KEY WORDS: carrageenan; monosodium glutamate; acid phosphatase; cathepsin B; blood; liver; lungs.

Адреса для листування: М. І. Марущак, Тернопільський національний медичний університет імені І. Я. Горбачевського мОз України, майдан Волі, 1, Тернопіль, 46001, Україна, e-mail: marushchak@tdmu.edu.ua. 